Sains Peternakan Vol. 13 (1), Maret 2015: 52-56

ISSN $1693-8828$

\title{
Kualitas Karkas Ayam Kampung yang Diberi Ransum Mengandung Omega-3 Minyak Ikan
}

\author{
Jein Rinny Leke ${ }^{1 \mathrm{a}}$, Vony Rawung ${ }^{1 \mathrm{~b}}$, Jacqulein Laihad ${ }^{1 \mathrm{~b}}$, Jet S. Mandey ${ }^{2 \mathrm{~b}}$, Linda Tangkau ${ }^{1 \mathrm{~b}}$ \\ ${ }^{1}$ Jurusan Produksi Unggas, Fakultas Peternakan, Universitas Sam Ratulangi \\ ${ }^{2}$ Jurusan Nutrisi dan Makanan Ternak, Fakultas Peternakan, Universitas Sam Ratulangi \\ ${ }^{a}$ Email: rinileke@yahoo.com
}

\begin{abstract}
ABSTRAK
Tujuan penelitian ini untuk mengetahui kualitas karkas ayam kampung yang diberi ransum mengandung omega-3 minyak ikan. Penelitian ini menggunakan Rancangan Acak Lengkap (RAL) dengan 5 perlakuan dan 5 ulangan, setiap ulangan 4 ekor ayam buras. Apabila perlakuan menunjukkan signifikasi, maka dilanjutkan dengan Duncan's Multiple Range Test. Perlakuan penelitian terdiri dari minyak ikan yaitu $\mathrm{R} 0=0 \%$ (pakan basal), R1 = (pakan basal 98,5\%+1,5\% MI), R2 = (pakan basal 98\%+2\% MI), R3 = $($ pakan basal 97,5\%+2,5\% MI), R4 = (pakan basal 97\%+3\% MI). Variabel yang diamati adalah bobot dada (g), bobot paha $(\mathrm{g})$, bobot punggung $(\mathrm{g})$ dan bobot sayap $(\mathrm{g})$. Hasil penelitian menunjukkan bahwa penggunaan minyak ikan dalam pakan memberikan pengaruh sangat nyata $(\mathrm{P}<0,01)$ terhadap bobot dada dan bobot paha, namun memberikan pengaruh yang tidak nyata $(\mathrm{P}>0,05)$ terhadap bobot punggung dan bobot sayap. Kesimpulan bahwa kualitas karkas terdiri bobot dada, bobot paha, bobot punggung dan bobot sayap ayam kampung meningkat dengan pemberian ransum minyak ikan sampai pada level $3 \%$.
\end{abstract}

Kata kunci: karkas, ayam kampung, minyak ikan.

\section{The Carcass Quality of Native Chicken by Rations Containing Omega-3 Fish Oil}

\begin{abstract}
The purpose of this study to determine the quality of chicken carcasses were given rations containing omega-3 fish oil. This study uses a Completely Randomized Design (CRD) with 5 treatments and 5 replications, each replication 4 free-range chickens. If treatment showed significance, then continued with Duncan's Multiple Range Test. The treatment consisted of fish oil that is RO=0\% (basal feed), RI = (basal feed 98,5\%+1,5\% MI), R2 = (basal feed 98\%+2\% MI), R3 = (basal feed 97,5\%+2,5\% MI), R4 = (basal feed $97 \%+3 \% \mathrm{MI})$. The variables measured were the weight of the chest $(\mathrm{g})$, the weight of the thigh $(\mathrm{g})$, the weight back $(g)$ and wing weight $(g)$. The results showed that the use of fish oil in the diet provides highly significant effect $(P<0,01)$ in the weight of the chest and thigh weights, but the effect is not significant $(P>0,05)$ to the weights and the weight of the wing backs. The conclusion that the quality of carcass weights comprised chest, thigh weight, the weight of the back and the weight of chicken wings increased the ration of fish oil to the level of $3 \%$.
\end{abstract}

Keywords: carcass, chicken, fish oil.

\section{PENDAHULUAN}

Pemenuhan sumber protein hewani yang semakin meningkat sebagai salah satu nutrien penting bagi manusia mutlak harus dipenuhi, hal ini seiring meningkatnya kesadaran masyarakat tentang pentingnya peningkatan gizi keluarga. Daging unggas seperti ayam kampung kerap menjadi pilihan sebagai sumber protein hewani karena harganya yang 
relatif terjangkau. Selain itu unggas memilki pertumbuhan yang cepat, sehingga lebih cepat dipanen untuk kebutuhan pasar.

Peningkatan konsumsi daging ayam kampung semakin meningkat. Hal ini sejalan dengan permintaan populasi ayam buras di Indonesia sejak tahun 2002 tercatat 298,43 juta ekor, sedangkan pada tahun 2006 tercatat 298,43 juta ekor. Jadi, selama kurun waktu 4 tahun terjadi kenaikan 23,14 juta ekor atau naik sebanyak 5,78\% pertahun. Ayam buras mampu memberikan kontribusi terhadap telur sebesar 181,1 ribu ton serta daging sebesar 322,780 ton yang setara dengan $15,59 \%$ dari total produksi daging nasional atau menyumbangkan $23,82 \%$ dari total daging unggas. Sebagai salah satu sumber pangan, ayam buras memberikan kontribusi $13,92 \%$ dari kebutuhan protein (Data Statistik Ditjen Peternakan, 2006).

Ayam kampung memiliki laju pertumbuhan relatif lambat jika dibandingkan dengan ayam ras. Ayam kampung berdasarkan bobot badan dapat digolongkan menjadi ayam yang memiliki bobot badan tipe medium memilki bobot badan sekitar $2,5 \mathrm{~kg}$ saat mencapai dewasa kelamin dan ayam kampung tipe ringan adalah ayam yang memiliki bobot badan sekitar $1,5 \mathrm{~kg}$ pada saat dewasa (umur diatas 24 minggu) (Suprijatna, 2010).

Pakan merupakan faktor terpenting dalam suatu pemeliharaan ayam kampung. Komposisi nutrien ayam kampung sangat menentukan keberhasilan pertumbuhan dan produksi daging. Pakan ayam kampung yang dipelihara intensif. Penelitian Zainuddin et al. (2004) menunjukkan bahwa untuk ayam kampung baik yang sudah diseleksi selama 6 generasi maupun ayam kampung yang tidak diseleksi taraf protein $15 \%$ dengan energi metabolis $2900 \mathrm{kkal}$ sudah optimal.

Minyak ikan (MI) adalah produk samping dari proses by product dari limbah ikan cakalang dan pemanfaatannya masih kurang optimal, hanya sebagai limbah pabrik. Hasil analisis Laboratorium Departemen Ilmu dan Teknologi Pangan, Bogor (2015) menunjukkan asam lemak omega-3 yaitu 0,69 $\mathrm{mg} / 100 \mathrm{~g}$, asam lemak omega-6 yaitu 0,03 $\mathrm{mg} / 100 \mathrm{~g}$, asam lemak omega-9 yaitu 0,18 mg/100 g. Pemanfaatan MI sebagai pakan ternak terutama ayam kampung dilakukan untuk mendapatkan kualitas karkas. MI mengandung asam lemak Eicosapentaenoic acid (EPA) dan Docosahexaenoic acid (DHA). Hasil survey Milo (2005) menyebutkan bahwa $60 \%$ masayarakat percaya bahwa omega-3 penting bagi kesehatan dan $80 \%$ hubungan dengan konsumsi ikan. Penelitian ini bertujuan untuk mengetahui pengaruh pemberian ransum mengandung omega-3 minyak ikan terhadap kualitas karkas ayam kampung.

\section{MATERI DAN METODE}

\section{Materi}

Penelitian menggunakan 100 ekor ayam kampung umur 20 minggu. Ayam kampung dipelihara dalam kandang percobaan dengan sistem baterey, dengan ukuran $25 \times 35 \times 35 \mathrm{~cm}$. Masing-masing unit kandang diisi oleh 4 ekor ayam buras. Setiap kandang dilengkapi tempat makan, minum dan lampu. Ayam kampung dipelihara selama 6 minggu. Terdapat 5 perlakuan dalam tahap penelitian ini. Perlakuan merupakan P0 (pakan basal), P1 (pakan basal 98,5\%+1,5\% minyak ikan), P2 (pakan basal 98\%+2\% minyak ikan), P3 (pakan basal 97,5\%+2,5\% minyak ikan), P4 (pakan basal 97\%+3\% minyak ikan) dan lima ulangan. Ransum disusun dengan kandungan energi berkisar $2900 \mathrm{kkal} / \mathrm{kg}$, dengan protein $20 \%$. Kebutuhan asam amino vitamin dan mineral sesuai dianjurkan oleh National Research Council of Poutry (1994). Pakan penyusun ransum terdiri dari jagung, dedak halus, tepung ikan, konsentrat, tepung bungkil kedelai, minyak ikan. Minyak ikan diperoleh dari PT Nichindo, Kabupaten Minahasa Selatan, Provinsi Sulawesi Utara, yang 
sebelum digunakan dilakukan proses pemurnian terlebih dahulu. Susunan dan

kandungan nutrien ransum dapat dilihat pada Tabel 1.

Tabel 1. Susunan dan Kandungan Nutrien Ransum

\begin{tabular}{lllllll}
\hline Ransum & $\begin{array}{l}\text { Jagung } \\
\text { kuning }(\%)\end{array}$ & $\begin{array}{l}\text { Dedak halus } \\
(\%)\end{array}$ & $\begin{array}{l}\text { Tepung } \\
\text { ikan }(\%)\end{array}$ & $\begin{array}{l}\text { Konsentrat } \\
(\%)\end{array}$ & $\begin{array}{l}\text { Tepung } \\
\text { kedelai }(\%)\end{array}$ & $\begin{array}{l}\text { Jumlah } \\
(\%)\end{array}$ \\
\hline Basal & 45 & 9 & 12 & 25 & 9 & 100 \\
\hline
\end{tabular}

Tabel 2. Formulasi Susunan Ransum Penelitian

\begin{tabular}{lccccc}
\hline \multicolumn{1}{c}{ Zat Makanan dan Energi Metabolis } & R0 & R1 & R2 & R3 & R4 \\
\hline Protein (\%) & 20,77 & 20,62 & 20,56 & 20,51 & 20,46 \\
Lemak(\%) & 6,83 & 7,1 & 7,48 & 7,85 & 8,23 \\
Serat Kasar (\%) & 4,83 & 4,75 & 4,73 & 4,70 & 4,68 \\
Calsium (\%) & 0,82 & 0,82 & 0,82 & 0,82 & 0,82 \\
Phospor (\%) & 0,81 & 0,81 & 0,81 & 0,81 & 0,81 \\
Energi Metabolis (Kkal/kg) & 2905 & 2959 & 2969 & 2978 & 2988 \\
\hline
\end{tabular}

Keterangan: R0 = Pakan basal, R1: RB = 98,5\%+1,5\% minyak ikan, R2 = 98\%+2\% minyak ikan, R3 = RB $97,5 \%+2,5 \%$ minyak ikan, R4 = RB 97\%+3\% minyak ikan.

\section{Metode Penelitian}

Rancangan percobaan yang digunakan adalah rancangan acak lengkap dengan lima perlakuan dan empat ulangan. Perlakuan berupa tingkat penggunaan minyak ikan dalam ransum $(0 \% ; 1,5 \% ; 2 \% ; 2,5 \%$ dan $3 \%)$. Model matematis analisis data hasil percobaan sebagai berikut:

$$
Y i j=\mu+T i+\epsilon i j
$$

Keterangan :

Yij = Respon yang diamati

$\mu=$ Rataan populasi

$\mathrm{Ti}=$ Efek ransum ke- $\mathrm{i}$

$\epsilon_{\mathrm{ij}}=$ Galat percobaan dari perlakuan untuk ransum ke-i ulangan ke-j

Asumsi yang paling mendasar dari model diatas adalah galat percobaan harus timbul secara acak, menyebar secara bebas dan normal dengan nilai tengah sama dengan nol dan ragam $\delta^{2}$ atau ditulis sebagai $\epsilon i j$ $\sim \mathrm{NI}\left(0, \delta^{2}\right)$.

\section{Parameter yang Diamati}

Potongan karkas adalah karkas yang telah dipotong-potong dalam empat bagian besar (Henrickson, 1978):

a) Bagian dada (breast): Bagian karkas yang dipotong dari persendian tulang belikat sampai batas tulang punggung. Bagian dada terdiri dari tulang berbentuk "V" (wish bone).

b) Bagian punggung (back): Bagian karkas yang dipotong dari perbatasan tulang rusuk terakhir dan persendian tulang paha (femur) kiri dan kanan.

c) Bagian paha (leg): Bagian karkas yang dipotong dari persendian tulang paha (femur) dan tulang punggung (ilium). 
Bagian paha terdiri atas paha atas (thigh) dan paha bagian bawa (drum stick).

d) Bagian sayap (wing): Bagian karkas yang dipotong dari perbatasan persendian tulang pangkal lengan (humerus) dengan persendian tulang belikat (coracoids).

\section{Analisis Data}

Data hasil penelitian diuji statistik menggunakan Rancangan Acak Lengkap. Jika terdapat perbedaan yang nyata antar perlakuan maka dilakukan uji lanjut menggunakan Duncan's Multiple Range Test (Steel dan Torrie,1993).

\section{HASIL DAN PEMBAHASAN}

Tabel 3. Bobot Dada, Bobot Paha, Bobot Punggung, Bobot Sayap Ayam Kampung yang Diberi Ransum Omega-3 Minyak Ikan

\begin{tabular}{lccccc}
\hline \multirow{2}{*}{ Parameter } & \multicolumn{5}{c}{ Perlakuan } \\
\cline { 2 - 5 } & $\mathrm{R} 0$ & $\mathrm{R} 1$ & $\mathrm{R} 2$ & $\mathrm{R} 3$ & $\mathrm{R} 4$ \\
\hline $\begin{array}{l}\text { Bobot dada } \\
\text { (gram) }\end{array}$ & $216,60 \pm 9,81^{\mathrm{a}}$ & $218,48 \pm 12,88^{\mathrm{b}}$ & $221,4 \pm 17,02^{\mathrm{b}}$ & $242,24 \pm 10,12^{\mathrm{c}}$ & $246,40 \pm 13,48^{\mathrm{c}}$ \\
$\begin{array}{l}\text { Bobot paha } \\
\text { (gram) }\end{array}$ & $237,80 \pm 25,26^{\mathrm{a}}$ & $335,52 \pm 22,04^{\mathrm{c}}$ & $328,84 \pm 25,68^{\mathrm{b}}$ & $341,36 \pm 29,81^{\mathrm{c}}$ & $350 \pm 35,77^{\mathrm{C}}$ \\
$\begin{array}{l}\text { Bobot } \\
\text { punggung } \\
\text { (gram) }\end{array}$ & $187,5 \pm 31,00$ & $227,40 \pm 31,43$ & $232,50 \pm 34,75$ & $243 \pm 20,87$ & $245,50 \pm 21,86$ \\
$\begin{array}{l}\text { Bobot sayap } \\
\text { (gram) }\end{array}$ & $115 \pm 13,17$ & $136,32 \pm 11,26$ & $131,86 \pm 14,81$ & $139 \pm 20,82$ & $135,50 \pm 13,82$ \\
\hline $\begin{array}{l}\text { Keterangan: Superskrip pada baris yang berbeda menunjukkan berbeda sangat nyata }(\mathrm{P}<0,01) . \\
\end{array}$
\end{tabular}

Rataan bobot dada, bobot paha, bobot punggung dan bobot sayap ayam kampung yang diberi ransum mengandung minyak ikan dapat dilihat pada Tabel 3. Hasil penelitian ini menunjukkan bahwa bahwa bobot dada memberikan pengaruh yang sangat nyata $(\mathrm{P}<$ 0,01). Hal ini menunjukkan bahwa pemberian minyak ikan sampai level 3\% memberikan pengaruh sangat nyata terhadap bobot dada. Bobot dada pada penelitian ini berkisar antara 216,60-246,40 gram. Rusmana (2010) menunjukkan bahwa bobot dada berkisar antara 145-167 gram dengan pemberian ransum mengandung minyak ikan lemuru sampai level 5\% dengan level protein berkisar $18 \%$ dan energi metabolis $2800 \mathrm{kkal} / \mathrm{kg}$. Hasil penelitian yang didapat menunjukkan bahwa mempunyai bobot dada lebih tinggi, hal ini disebabkan pada penelitian menggunakan minyak ikan dengan level protein berkisar $20 \%$ dan energi metabolis $2900 \mathrm{kkal} / \mathrm{kg}$. Dewi et al. (2009) bahwa ayam kampung diberi ransum mengandung imbangan energi dan protein yang lebih tinggi menghasilkan berat badan lebih tinggi secara nyata dibanding ransum mengandung imbangan energi dan protein lebih rendah pada umur 8 minggu.

Hasil penelitian menunjukkan bahwa bobot paha menujukkan perbedaan sangat nyata $(\mathrm{P}<0,01)$. Hal ini menunjukkan bahwa pemberian minyak ikan sampai level 3\% memberikan pengaruh sangat nyata terhadap bobot paha. Rataan pada penelitian ini berkisar antara 237,80-350 gram dengan 
pemberian minyak ikan 5\%. Hal ini diakibatkan karena ayam kampung mengkonsumsi ransum yang level protein dan energi metabolis dalam ransum tidak hanya digunakan untuk membentuk karkas, juga digunakan untuk bagian-bagian lain dari tubuh ayam. Rusmana (2010) menunjukkan bahwa bobot paha berkisar antara 206-232 gram, dengan minyak ikan lemuru $5 \%$.

Hasil penelitian ini menunjukkan bahwa bobot punggung dan bobot sayap menunjukkan berbeda nyata $(\mathrm{P}>0,05)$. Hal ini menunjukkan bahwa pemberian minyak ikan sampai level 3\% tidak memberikan pengaruh nyata terhadap bobot punggung dan bobot sayap. Penelitian Rusmana (2010) menunjukkan bahwa pemberian minyak ikan lemuru sampai 5\% tidak memberikan pengaruh yang nyata $(\mathrm{P}>0,05)$ terhadap bobot punggung dan bobot sayap. Dalam memenuhi selera konsumen terhadap permintaan daging yang siap untuk dimasak, maka biasanya produsen mengolah karkas dalam bentuk potongan karkas. Bagian dan potongan karkas bermacam-macam tergantung selera dan daerah penjualan. Ayam kampung biasanya dipotong komersial dibagi menjadi empat bagian (quarter). Markley dkk. (1980) membagi karkas ayam menjadi empat potongan besar yaitu paha (breast), sayap (wing), punggung (back) dan paha (leg).

\section{DAFTAR PUSTAKA}

Dewi, G.A.M.K., I.G. Mahardika, I.K. Sumadi, I.M. Suasta dan I.M. Wirapartha. 2009. Peningkatan Produktivitas Ayam Kampung Melalui Kebutuhan Energi dan Protein Pakan. Laporan Penelitian Hibah Bersaing, Fapet-UNUD. Denpasar.
Ditjen Peternakan. 2006. Buku Statistik Peternakan. Direktorat Jenderal Peternakan. Departemen Pertanian. Jakarta.

Henrickson. 1978. Meat Poutry and Sea Food Technology. Prentice Hall Inc. Engelewood Cliffs. New Jersey.

Markley, J.W., B.T, Weinland, G.W. Malone and G.W. Chaloupka. 1980. Evaluation of Commersial Broiler Crosses. Eviscerated Yield and Compnent Part. Poult.Sci.

Milo, L. 2005. Functional Fatty Acids. Food Tech. 59, 63-68

Rusmana. D.D. Natawihardja dan I. Irfana. 2010. Performan Karkas Ayam Kampung Super CP 808 Periode Pertumbuhan Yang Diberi Ransum Yang mengandung Minyak Ikan Lemuru.

Suprijatna Ejeng. 2010. Strategi Pengembangan Ayam Lokal Berbasis Sumber Daya Lokal dan Berwawasan Lingkungan. Seminar Nasional Unggas Lokal ke IV, 7 Oktober 2010. Fakultas Peternakan Universitas Diponegoro.

Steel dan Torrie. 1993. Prinsip dan Prosedur Statistika, Sumantri B, Penerjemah; Jakarta. Penerbit PT Gramedia Pustaka Utama. Terjemahan dari: Principles and Procedured of Statistics.

Zainudin. D., B. Gunawan, S. Iskandar dan E. Juarini. 2004. Pengujian efisiensi penggunaan gizi ransum pada ayam kampung (F-6) periode produksi telur secara biologis dan ekonomis. Prosiding Seminar Nasional Teknologi Peternakan dan Veteriner. Pusat Penelitian dan Pengembangan Peternakan. Badan Penelitian dan Pengembangan Pertanian. 